\title{
Cities of race hatred? \\ The spheres of racism and anti-racism \\ in contemporary Australian cities
}

\author{
Kevin Dunn, James Forrest, Rogelia Pe-Pua, \\ Maria Hynes, Karin Maeder-Han
}

\begin{abstract}
Cities are indeed places of everyday racism, experienced as ethnocentrism, prejudice and ethnic-based hatred. Drawing on an Australia-wide telephone survey of respondents' experiences of 'everyday' racism in various contexts, conducted in 2006, we examine forms of racist experience, as well as the contexts and responses to those experiences for Sydney, Melbourne and Perth, Australia's main immigrant-receiving cities. Results show that between 1 in 10, and 1 in 3 respondents, depending on their background and situation, experience some form of 'everyday' racism. However, this particular aspect of urban incivility is shadowed by everyday good relations. There is what might be called a 'geography of cultural repair' and cultural maintenance within the cosmopolitan city. There is strong support for anti-racism policy. Where action is taken in response to racism, it is determined by everyday confrontations and attempts at direct reconciliation. Formal complaints and reports are much rarer forms of anti-racism. In this paper, we advocate a pragmatic on-going, agonistic politics of cultural exchange and tolerance.
\end{abstract}

\section{Racism and anti-racism}

The nature of racism in Australia has been acknowledged in a series of government reports, and in some incisive ethnographic work. Also, there has been an extensive qualitative investigation of the mechanisms through which intolerance is reproduced, most notably through a critical analysis of news media and the statements of opinion makers, including political leaders. However, there is a lack of comprehensive data on the nature of racism in Australian society. To assist in remedying this gap, we have sought to generate comprehensive empirical data on the extent and variation of racist attitudes and experiences of racism, to inspire or guide anti-racism initiatives. Thus Challenging Racism: The Anti-racism Research Project (hereafter The Challenging Racism Project) has been able to establish, empirically, that there is a recognisable problem with racism in Australia (Dunn et al., 2004).

There is evidence that over the last few years, the number of racist incidents in Australia has grown. In the wake of the New York 11th September 2001 and the Bali 12th October 2002 terror attacks, the Islamic Council of New South Wales found that reports of racist violence and incivilities against Australian Muslims dramatically escalated (ICNSW, 2004; also Poynting \& Noble, 2004). The Human Rights and Equal Opportunity Commission (HREOC) Ismaع inquiry (2004, pp.54-57), for example, heard evidence of considerable discrimination and 'race talk' against Arab and 
Muslim Australians. Poynting and Noble (2004, p.6) found that 75 per cent of respondents in their survey of Muslims and Arabs had experienced higher rates of racist abuse or violence since 9/11. Other reports confirm that such incivilities against Muslims in public places are all too common. In 2001, we commissioned a telephone survey of residents in New South Wales and Queensland (n = 5056) on attitudes towards cultural diversity, specific cultural groups and racism (Forrest \& Dunn, 2006). The survey also included some pilot questions on experience of racism. We found that 'everyday racisms’ were more prevalent than institutional forms. Institutional forms of racism included the workplace, educational settings, dealings with police and when seeking housing. The experience of racism in these settings impacted upon close to one in six Australians (Dunn et al., 2005). However, almost a quarter of Australians experienced 'everyday’ forms of racism, encountered in shops, restaurants, at sporting events, or in the form of disrespectful treatment on the basis of ethnic identity, or name-calling. The most frequent experience of racism was in the form of disrespectful treatment and name-calling.

Similarly, Loosemore and Chau (2002, p.98) found very high rates of racist experiences by AsianAustralians in construction workplaces, principally including 'racist name-calling' (66\%), 'racist jokes’ (67\%), ‘ racist material’ (64\%), ‘segregation’ (56\%), ‘offensive gestures’ (49\%) and 'physical abuse' (56\%). They concluded that "racism is seen [by their respondents] as an inevitable consequence of working in the construction industry, one that is largely ignored by managers and accepted and tolerated by workers”. During 2003, the Racism Monitor collected data from community organisations on the experience of racism, and found that acts of discrimination, verbal abuse and violence were commonplace for Australian Muslims (Browning et al., 2003). Such incivility was so widespread that Islamic organisations had come to see it as an 'ordinary experience' of Australian life: “it happens so often and goes unnoticed, therefore we have learnt to accept this sort of bad behaviour” (quoted in Browning et al., Racism Monitor, 2003, p.7). These findings were confirmed in the Targeted Report on the experiences of racism in Sydney following the September $11^{\text {th }}$ terror events (Dreher, 2005, pp. 23-25).

The experience of these forms of racist behaviour constructs fearful social environments that can deprive people of their freedom of movement, expression and affiliation. The National Inquiry into Racist Violence (Human Rights and Equal Opportunity Commission, 1991, pp.387-388) pointed out that such racism generated a "threatening environment". Thus "(W)hat is seen and heard in schools and neighbourhoods ... shapes understandings of self” (Amin \& Thrift, 2002, p.292). An environment in which certain groups are repeatedly denigrated through racist talk and other racist 
incivilities can fundamentally undermine the sense of citizenship and belonging of those disparaged. In circumstances where such talk becomes common, the uneven dispensation of citizenship and belonging becomes normalized, unquestioned, and harder to challenge. What emerges has been described by Kobayashi and Peake (2000) as the 'normalcy' of racism, where racism is almost unnoticed or seen as an aberration (McGuiness, 2000). Certain forms of exclusive situational norms are generated. In the urban context, such circumstances provide the makings of cities where racial hatred is insidiously normalized.

Data gathered in the surveys has also targeted tolerance or beliefs that might be considered antiracist. Our most recent data base uses experiences of racism rather than attitudes, and we report on some of those findings here - on experiences of racist behaviour - with an emphasis on 'hate talk' versions of racism. Yet we also agree with Thrift's (2005) assertion that there are substantial, and largely unreported, feelings about anti-hatred in the city, what he referred to as 'repair work'. So, while there is a good deal of everyday racism in the city, there is also evidence of everyday antiracism. Both aspects are reported on here. Our focus upon these issues marks a transition in The Challenging Racism Project, from the study of racism towards the study of anti-racism.

\section{Method and purpose}

Collection of data on the experience of discrimination is an innovative approach to developing indicators on the extent of racism, and derives in part from work conducted by a research team at the University of Michigan, USA (The University of Michigan, Institute for Social Research, 2001). Such forms of indicators on the extent of racism have not before been empirically applied in the Australian context. Between $24^{\text {th }}$ January and $24^{\text {th }}$ March 2006 a telephone survey was undertaken of 4020 residents across Australia (with the exception of Tasmania). Drawing on the results of that survey, we focus here on just over 1700 responses from Australia’s three major immigrantreceiving cities - Sydney (with some 38 per cent of new arrivals in recent years), Melbourne (27 per cent) and Perth (9 per cent) (Department of Immigration and Multicultural Affairs - DIMA - 2005). Today, for example, 43.2 per cent of Sydney’s population is of non-English speaking background ancestry, compared with 41.4 per cent in Melbourne and 30 per cent in Perth.

Some new survey questions were developed within the categories of race talk, exclusion, unfair treatment, and physical attack. Data were also collected on the context of racist incidents with respect to location, actions and reactions of victims, victims' feelings and outcomes, (such as impacts on sense of belonging, expressions of regret and the like). Opinions on the need for anti- 
racism initiatives were also examined. A national survey, as such, cannot produce insights available from other in-depth approaches to understanding the experience of racism, such as qualitative methodologies (see Lamont et al., 2002, p.395). However, survey data does have advantages of scope, and facilitates assessments of breadth and variation. Modood (2000, p.180), when commenting on the 4th National Survey of Ethnic Minorities in Britain, observed that the "survey has the potential to offer what small-scale ethnographic studies, armchair theorising, and political wishful thinking can not”. Surveying facilitates a stronger grasp of the extent and variation of the experience of racism, and produces data that are more easily defensible in the public realm. As a consequence, surveys retain strong currency within discussions of policy. Nevertheless, this national survey did collect some more nuanced qualitative data on the feelings associated with the experience of racism.

There are three broader purposes of The Challenging Racism Project that should be outlined before moving on to discussion of results. Firstly, a central conviction is that while racist attitudes and the experience of 'everyday racism' are quite prevalent in Australian society their occurrence varies noticeably from place to place and in often quite specific ways (Forrest \& Dunn, 2006, 2007). Place (context) matters. This regionally varied frequency and nature of racism means that anti-racist initiatives need to be geographically sensitive. Yet the spatial variations in racism have been largely overlooked by anti-racism campaigns in Australia.

To assist with the consequential need for the local development of anti-racism initiatives, our findings have been posted within a university website since December 2004 (see http://www.uws.edu.au/social_sciences/soss/research/challenging_racism ). This includes data on racist attitudes and experiences arranged by Statistical Districts including some ethnicity data drawn from the 2001 ABS Census. Our intention is that these data, and PDFs of publications, will assist local governments and grass roots groups in the development of anti-racism strategies. The site is up-dated on an on-going basis.

At this point, mention should also be made of an emerging form of political correctness that proscribes the discussion of racism (see Hall, 2000, p.222; Hesse, 2000, pp.5-10; Warren, 2000, pp.145-54). Activists who draw public attention to racism are often accused of 'playing the race card', or of themselves being racist. Through a clever discursive turn the opprobrium associated with racism has shifted somewhat to those who expose it. Nonetheless, there is a need for the realities of racism to be acknowledged. This is essential for enabling public policy responses; anti- 
racism. "Conflict avoidance”, evasiveness, and the downplaying of racial inequality are key means by which racism is reproduced (Warren, 2000).

\section{The everyday experience of racism (2006)}

Around one-in-five (20 to 22\%) survey respondents in Sydney, Melbourne and Perth indicated that they had experienced forms of race hate talk (Table 1). This included, for example, verbal abuse, name-calling, racist slurs, or ridicule based on a person's cultural background. This finding accords well with earlier, pilot results which showed that 25 per cent had experienced racialised insults (Dunn et al, 2005). The recent survey results are the most specific in the wording of the question, and they more carefully operationalise specific forms of racist incidents. At any rate, experience of race talk was the highest of the four categories of racism experienced by our respondents. For racist exclusion the rate varied between 12 and 14 per cent; rates for unfair treatment and forms of physical attack were lower again. In each case, Sydney, with more of the post-White Australia (post-the early 1970s) immigrants in its population mix, emerges as slightly more exposed to racist experiences than the other two cities. However, Perth, which has become an important immigrantreceiving city over the past decade or so, is close behind Sydney in some forms of experience, such as racist talk and the most severe form of experience, physical attack.

Table 1: Experience of racism in major immigrant-receiving cities, Sydney/Melbourne/Perth across four major Categories of 'everyday racism', 2006

\begin{tabular}{|l|l|c|c|c|c|}
\hline Category of racist incident & \multirow{3}{*}{ Yes } & \multicolumn{3}{|c|}{ No \& refused } \\
\cline { 1 - 4 } Have you: & & $\mathrm{n}$ & $\%$ & $\mathrm{n}$ & $\%$ \\
\hline Experienced RACIST TALK, for example, verbal & Sydney & 169 & 22.1 & 594 & 77.7 \\
abuse, name-calling, racist slur, or ridicule, based & Melbourne & 131 & 19.7 & 534 & 80.2 \\
on your cultural background? & Perth & 67 & 20.7 & 219 & 79.3 \\
\hline Experienced EXCLUSION, e.g., making you feel & Sydney & 108 & 14.2 & 655 & 85.8 \\
like you don't belong or you are inferior, or people & Melbourne & 86 & 12.9 & 579 & 86.9 \\
are avoiding you because of your culture? & Perth & 32 & 11.6 & 244 & 88.4 \\
\hline Experienced UNFAIR TREATMENT, e.g., & Sydney & \multirow{2}{*}{80} & 10.5 & 683 & 89.5 \\
denied service or employment, treated badly or & Melbourne & 49 & 7.4 & 617 & 92.6 \\
with suspicion because of your cultural & Perth & 20 & 7.2 & 256 & 92.8 \\
background? & & 48 & 6.3 & 715 & 93.7 \\
\hline Experienced ATTACK, for example, physically & Sydney & 30 & 4.5 & 636 & 95.5 \\
attacking, abusing or threatening you or your & Melbourne & 18 & 6.5 & 258 & 93.5 \\
property because of your cultural background? & Perth & 18.5 \\
\hline
\end{tabular}

Source: The Challenging Racism Project Experiences of Racism Survey, 24.1.2006 - 24.3.2006. 


\section{The experience of hate speech}

For about 69 per cent of the people who had experienced racist talk, this took the form of being called an offensive slang name for their cultural group (Table 2). Other race talk categories included: verbal abuse (62\%), stereotypes (61\%), offensive gestures (56\%) poor portrayal of cultural group (54\%) and racist jokes (52\%).

Table 2: Specific forms of 'race talk’ experiences in Sydney, Melbourne \& Perth, 2006

\begin{tabular}{|l|c|c|}
\hline & $\begin{array}{c}\% \text { of race talk } \\
\text { experienced }\end{array}$ & $\begin{array}{c}\% \text { of all } \\
\text { respondents }\end{array}$ \\
\hline $\begin{array}{l}\text { You have been called an offensive slang name for } \\
\text { your cultural group? }\end{array}$ & $69.2 \%$ & $14.5 \%$ \\
\hline $\begin{array}{l}\text { You have been sworn at, or verbally abused, because } \\
\text { of your cultural background? }\end{array}$ & $61.6 \%$ & $12.9 \%$ \\
\hline $\begin{array}{l}\text { You have heard or read comments that are } \\
\text { stereotypical of your cultural group? }\end{array}$ & $61.1 \%$ & $12.8 \%$ \\
\hline $\begin{array}{l}\text { You have heard talk or read something that portrays } \\
\text { your cultural group in a poor light? }\end{array}$ & $54.1 \%$ & $11.3 \%$ \\
\hline $\begin{array}{l}\text { You have been a target of racist jokes, songs, or } \\
\text { teasing? }\end{array}$ & $52.4 \%$ & $11 \%$ \\
\hline $\begin{array}{l}\text { Someone made offensive gestures towards you } \\
\text { because of your cultural background? (hand gestures, } \\
\text { etc). }\end{array}$ & $51.5 \%$ & $10.8 \%$ \\
\hline
\end{tabular}

Source: The Challenging Racism Project, Experiences of Racism Survey, 24.1.2006 - 24.3.2006.

These everyday racist events were not necessarily rare. We asked 76 respondents in the three main cities who had been called an offensive slang name because of their cultural background how often that race talk occurred. Nearly half (some 42 per cent) said it occurred occasionally or more often, while $58 \%$ indicated that it was rare or had only happened once (Table 3).

Table 3: The frequency of being called an offensive slang name for a cultural group, Sydney, Melbourne and Perth, 2006.

\begin{tabular}{|l|c|c|}
\hline \multicolumn{1}{|c|}{ Frequency } & No. & \% \\
\hline Very often & 3 & 3.95 \\
\hline Often & 3 & 3.95 \\
\hline Occasionally & 26 & 34.21 \\
\hline Rarely & 29 & 38.16 \\
\hline Once only & 15 & 19.74 \\
\hline
\end{tabular}

Source: The Challenging Racism Project, Experiences of Racism Survey, 24.1.2006 - 24.3.2006. 


\section{Cultural unevenness}

In our pilot work we had found that everyday racisms experienced by Indigenous Australians were much higher than for non-Indigenous respondents, with forty-three per cent responding that they had been treated with disrespect on the basis of their ethnic background, and 37 per cent the recipient of racist abuse (Dunn et al., 2005). Close to one-in-two respondents who spoke a language other than English (LOTE), representing those with a non-English speaking background cultural heritage, at home or in the community, had reported being treated disrespectfully or abused on the basis of their ethnicity. On this basis our expectation in the current survey was that the experience of racism, including racist talk, would be culturally uneven, and that in general, non-AngloAustralians would report higher rates.

Table 4: Experience of racist talk, Australia-wide, by cultural categories, 2006

\begin{tabular}{|c|c|c|}
\hline & \multicolumn{2}{|c|}{$\begin{array}{l}\text { Have you experienced RACIST TALK, for } \\
\text { example, verbal abuse, name-calling, racist slur, or } \\
\text { ridicule based on your cultural background? }\end{array}$} \\
\hline & & Yes \% \\
\hline \multirow{2}{*}{$\begin{array}{l}\text { Do you speak a language other } \\
\text { than English (LOTE) at home or } \\
\text { in your community? }\end{array}$} & LOTE & 32.38 \\
\hline & non-LOTE & 15.30 \\
\hline \multirow[t]{4}{*}{ What is your religion? } & Christian & 17.44 \\
\hline & Non-Christian & 33.46 \\
\hline & No religion & 19.69 \\
\hline & Inadequately described & 34.68 \\
\hline \multirow{8}{*}{$\begin{array}{l}\text { What is the cultural heritage of } \\
\text { your mother/father?* }\end{array}$} & Oceania - Australian & 15.51 \\
\hline & Oceania - ATSI & 62.82 \\
\hline & Oceania - Other & 33.10 \\
\hline & European & 28.29 \\
\hline & Asian & 36.36 \\
\hline & $\begin{array}{l}\text { Nth African \& Mid- } \\
\text { Eastern }\end{array}$ & 45.26 \\
\hline & People of the Americas & 42.86 \\
\hline & Sub-Saharan African & 32.08 \\
\hline
\end{tabular}

*Respondents identified the cultural heritage of mother and father separately. Multiple cultural heritage responses were therefore recorded (n:4368) exceeding total sample.

Source: The Challenging Racism Project, Experiences of Racism Survey, 24.1.2006 - 24.3.2006.

From the general question of whether respondents had experienced race talk, 33 per cent of LOTE respondents stated that they had, compared with only 15 per cent of non-LOTE respondents (Table 4). There were similar variations across the religious divide between Christian and non-Christian, with non-Christians more likely to experience racist talk. Indigenous Australians (see Oceania ATSI in Table 4) were much more likely to experience racist talk than other Australians 


\section{Context of offensive slang names}

Respondents were asked to provide details about the context of racist incidents, relating to location, (re)actions of the victim, feelings of the victim, and outcomes (impacts on sense of belonging, of regret). Of 247 respondents who reported that they had been called an offensive slang name for their cultural group, 76 were randomly selected and asked to provide detail on this experience. Close to half of the locations of these incidents were public spaces, such as in the street, or in shopping centres, clubs or at sporting events (Table 5). After that, educational settings and the workplace were key sites of such race talk.

Table 5: Locations where people were called an offensive slang name for their cultural group, 2006 (Melbourne, Sydney, Perth)

\begin{tabular}{|c|c|c|c|c|}
\hline Specific location & No. & Category & No. & $\%$ \\
\hline Street & 23 & \multirow{8}{*}{ Public space } & \multirow{8}{*}{63} & \multirow{8}{*}{$42.57 \%$} \\
\hline Shop or in a mall, shopping centre, market & 16 & & & \\
\hline Pubs, clubs, bar, disco, nite-club & 10 & & & \\
\hline Sporting event (player or spectator) & 5 & & & \\
\hline Public transport & 4 & & & \\
\hline Other public space (beach boating) & 3 & & & \\
\hline $\begin{array}{l}\text { Fast food place (e.g. McDonalds, KFC, } \\
\text { Subway, food courts) }\end{array}$ & 1 & & & \\
\hline Restaurant & 1 & & & \\
\hline High school & 18 & \multirow[t]{2}{*}{ Education } & \multirow[t]{2}{*}{31} & \multirow[t]{2}{*}{$20.95 \%$} \\
\hline Primary school or earlier education (child-care) & 13 & & & \\
\hline Workplace & 21 & Workplace & 21 & $14.19 \%$ \\
\hline Social event (party, event, get-together, BBQ) & 9 & \multirow{3}{*}{ Private space } & \multirow{3}{*}{15} & \multirow{3}{*}{$10.13 \%$} \\
\hline Own home (not party) & 3 & & & \\
\hline Friend's or relative's home (not party) & 3 & & & \\
\hline $\begin{array}{l}\text { In hospitals health centres, nursing home or } \\
\text { GP's room }\end{array}$ & 1 & & 1 & - \\
\hline Applying for a position (eg. At interview) & 1 & & 1 & - \\
\hline Other answer given & 16 & Other & & $10.81 \%$ \\
\hline TOTAL (of locations provided) & $148^{*}$ & & & \\
\hline
\end{tabular}

The total number of locations exceeds the total sample because multiple locations could be recorded.

Source: The Challenging Racism Project, Experiences of Racism Survey, 24.1.2006 - 24.3.2006.

Thus the picture emerging from these data is that the city exhibits a strong element of race hatred. These cities are also a places of strong cultural diversity. Racism (or at least race hate talk) is also more frequent within the public realms and spaces of the city. These racisms are 'everyday' in the sense of their informality, and the ways in which they can insidiously become seen as expected or normal. For example, one of our respondents stated in the survey that "After a while it [the racist experience] was accepted as a likelihood specific to that particular area”. 


\section{Anti-race-hatred I: responding to racism}

There are number of approaches to anti-racism. Some have a primary emphasis on improving attitudes to cultural diversity and difference, and improving dispositions towards specific cultural groups. These actions are intended to minimise the propensity for racism. Secondary level antiracism targets those who have been identified as likely to be involved in racist behaviour. In previous work we have examined attitudes, and commented on social and spatial variations in problematic attitudes and dispositions. And we have speculated on what that means for targeting anti-racism effort. Tertiary level anti-racism responds to actual racist events, we have examined this at the level of individuals who had experienced racism.

Of the 76 major city respondents who were asked for further details about being called an offensive slang name for their own cultural group, just under 70 per sent, did nothing about the incident (Table 6). On the one hand this might suggest that the racist incident was of a lower order and impact, negating the need for a response. However, the literature on the impacts of response on victims suggests that this finding is quite concerning. A Report released by the Victorian Health Promotion Foundation (2007, pp.19,27-29,52) includes a review of literature on effects on health and well-being of the experience of racism, including research on how victim response feeds into morbidity, especially in terms of mental health. A clear finding is that those people who take action in response to an experience of racism are at lesser risk of morbidity, and those who take no action are more likely to suffer health ill-effects (Paradies, 2006, pp.893-5). We asked those respondents who had experienced racism if they had ever regretted those occasions where they did not do anything about it. Twenty-eight per cent did have such regrets, although 55 per cent did not. The open response comments of those who had experienced racism provide an insight into the wellbeing effects.

“[I felt] Angry. And like - lashing out. But you can't, because it doesn't make any difference, and only reinforces the racists' ideas about your people”.

“A bit sad, but I just don't let it bother me too much or else it makes me think negative thoughts”.

“A bit upset, but not too worried because I'm going back to my country”.

"[I felt] Very satisfied that I didn't just take the abuse. I stood up to them then and there”. 
The effect of racism on health is primarily pertains to sense of self and mental health (see Begg et al., 2007; Paradies, 2006, pp. 895-6). What we have referred to as non-response has been characterised in the literature as 'passive responses', and include such things as the internalising of racism through unfavourable self-evaluations and stress associated coping mechanisms that involve health-damaging behaviour (smoking, alcohol use etc). The findings on non-response provide insights into the way that race talk can become normalised and unchallenged, and the deleterious social effects of that. The nature of the actions taken by those who experience race hate talk is informative. Only some 6 per cent officially reported the matter or consulted /confided with someone about it. The most frequently mentioned active response (22\%) was to confront the perpetrator in some manner, usually in a non-violent way, and in some circumstances to use humour or ridicule. This finding provides some clues as how best to support anti-racism that is targeted against race talk. Everyday racism needs everyday anti-racism. Methods to empower individuals (principally rhetorical strategies and discursive materials) in their confrontations with racism are critical. The policy responsibility has to be about leadership, to role modeling, and to the insertion of counter-racist norms and tropes. We need rhetorical tools that have everyday comprehension at the street level, in the changing room and in the school-yard. These could be, for example, antiracist catch phrases that are nationally-endorsed, easily deployed; and that rob commonsense racism of their power.

Table 6: Responses to being called an offensive slang name for a cultural group, Sydney/Melbourne/Perth 2006.

\begin{tabular}{|c|c|c|c|c|}
\hline Response & No. & Category & No. & $\%$ \\
\hline Ignored / pretended didn't happen or hear / did nothing & 78 & \multirow{4}{*}{ Nothing } & \multirow{4}{*}{99} & \multirow{4}{*}{$68.75 \%$} \\
\hline Got used to it, put up with it & 12 & & & \\
\hline Left/resigned from the committee/group & 7 & & & \\
\hline Laughed it off/laughed & 2 & & & \\
\hline Confronted perpetrator (non-violent) & 20 & \multirow{4}{*}{ Confronted } & \multirow{4}{*}{32} & \multirow{4}{*}{$22.22 \%$} \\
\hline Used humour or ridiculed the perpetrator & 6 & & & \\
\hline Physically confronted perpetrator /self-defence & 5 & & & \\
\hline Initiated a reconciliation / reasoning & 1 & & & \\
\hline Report to police & 2 & \multirow{3}{*}{ Reported } & \multirow{3}{*}{4} & \multirow{3}{*}{$2.78 \%$} \\
\hline Report to their employer/teacher/referee & 1 & & & \\
\hline Report to anti-discrimination authority/agency & 1 & & & \\
\hline $\begin{array}{l}\text { Confided / discussed with friend/family/close } \\
\text { colleague/neighbour }\end{array}$ & 4 & Consulted & 4 & $2.78 \%$ \\
\hline Other & 5 & Other & 5 & $3.47 \%$ \\
\hline TOTAL (number of responses recorded) & $\begin{array}{r}144 \\
*\end{array}$ & & & \\
\hline
\end{tabular}

*The total number of responses exceeds the total sample because multiple responses could be recorded.

Source: The Challenging Racism Project, Experiences of Racism Survey, 24.1.2006 - 24.3.2006. 


\section{Anti-race-hatred II: Attitudes}

In other surveys we have detected strong levels of support for cultural diversity among the Australian population. There was a sound rejection of the so-called 'old racisms' of racial supremacy and racial separatism (Dunn et al., 2004). We found that a significant majority of the population (83\%) acknowledged that there was ethnic prejudice in Australian daily life (Dunn et al., 2004, pp.418-420). However, we also found that many fewer people acknowledged that they were personally prejudiced (12\%). Nonetheless, those findings for NSW and Queensland generally indicate strong levels of public recognition that racism is a problem, which might well imply support for anti-racism. Survey data for Victoria (Victorian Health Promotion Foundation, 2007) and the ACT (Dunn \& White, 2008) demonstrated similar findings for the people of those jurisdictions.

In our national experiences survey, we asked city respondents for their views on the need for antiracism and on its likely efficacy. Results reveal that the overwhelming majority of respondents support the need for anti-racism (Table 7). Only five per cent saw no need for such action. We also asked respondents to comment on whether much can be done about racism. This was put forward as a despondent proposition: "Nothing can be done to minimise or fight racism in Australia”, to which 84 per cent disagreed, indicating their belief that something can be done to reduce racism. Almost 10 per cent thought that nothing could be done, and the remainder were unsure. These findings suggest that there is a substantial capacity for anti-racism initiatives in the city.

Table 7: Support for anti-racism initiatives in Sydney/Melbourne/Perth, 2006

\begin{tabular}{|l|c|}
\hline & \% Agree \\
\hline Something should be done to minimise or fight racism in Australia & 86.4 \\
\hline Nothing can be done to minimise or fight racism in Australia & \% Disagree \\
\hline
\end{tabular}

Source: The Challenging Racism Project, Experiences of Racism Survey, 24.1.2006 - 24.3.2006.

\section{Negotiating pessimism \& optimism}

Theory on cross-cultural relations in the city paints a mixed picture on the inevitability of racism. The Chicago School theorists thought racism was a temporary phenomenon that would dissipate with the assimilation of new migrant cohorts. Racism was therefore expected, but ephemeral. Other theory points to the structural bases of racism, and often its inevitability, where racism is anticipated 
in a capitalist or patriarchal society, or in a world ordered by independent and competitive nation states. Much of the policy talk on racism continues to perceive it as something that can be completely overcome. Too often in public policy discussions, anti-racism is discussed as a finite project (see a critique by Paradies, 2005, p. 4-5). That is, it is assumed that through some abstract or macro intervention, such as the proclamation and implementation of a policy of multiculturalism, we can erase racism. The logic that assumes there can be a one-off (often structural) fix to racism can be observed in the statements of some anti-racism conference aims such as in the title, "The National Conference to Erase Racism”, and in legislation such as the United Nation's International Convention on the Elimination of All Forms of Racial Discrimination (CERD), as well as private and NGO (non-Governmental Organisation) initiatives, such as “Let’s Kick Racism Out of Football”. We do not deny that these are laudable aims, and often useful interventions. The poetics of promising an end to racism probably have an effect (but perhaps less so with each reiteration). However, it is now quite clear from theory and empirical research that erasing racism would probably require the erasure of ethnic groups and ethnic differentiation. This is not likely, nor would the erasure of difference be desirable. The aim of anti-racism, then, should realistically be the amelioration and reduction of racism. It should be to enhance the celebration and valuing of difference. Anti-racism needs to be omnipresent, but it must also be varied, to address the every where (and every where different) manifestation of racism (Forrest \& Dunn, 2006, 2007). Furthermore, racism requires ongoing, long term policy attention, public action and development.

This also allows a more realistic view on the strategic and dynamic nature of anti-racism. It is not necessary for everyone, everywhere, for all time, to reach agreement on how we ought to live our lives, and to embrace all ways of life. It would be enough to have mutual obligations and strategic agreements about what should be tolerated, and what we will have to 'put up' with in our cities. Thrift (2005) reminds us there is as much capacity in the city for construction and repair as there is for destruction and injury. Our data point to the strong capacity for anti-racism, whether in the form of responses to racism or preparations against it.

\section{Acknowledgements}

We would like to acknowledge the professional data gathering of the Hunter Valley Research Foundation. We are also appreciative of the funding from the Australian Research Council (DP0345263), and are indebted to the 4020 Australians who shared their insights and opinions through the telephone survey. 


\section{Bibliography}

Amin, A. \& Thrift, N. 2002, 'Cities and ethnicities', Ethnicities, vol. 2, no. 3, pp. 291-300.

Browning, J., Jakubowicz, A. \& Gold, A. 2003, 'What can we say about racism in Australia? Discussion Paper No. 1', Racism Monitor.

Begg, S., Vos, T., Barker, B., Stevenson, C., Stanley, L. \& Lopez, A.D. 2007, The Burden of Disease and Injury in Australia 2003, Australian Institute of Health and Welfare, Canberra.

Dreher, T. 2005, Targeted; Experiences of Racism in NSW after September 11, 2001, University of Technology Sydney Press, Ultimo

Department of Immigration and Multicultural Affairs 2005, Longitudinal Survey of Immigrants to Australia - Wave 1, DIMA Research Section, Canberra.

Dunn, K.M., Forrest, J., Burnley, I. \& McDonald, A. 2004, 'Constructing racism in Australia', Australian Journal of Social Issues, vol. 39, no. 4, pp. 409-430.

Dunn, K.M., Forrest, J., Pe-Pua, R. \& Smith, S. 2005, 'Experiences of racism in the Australian body politics: extent, spheres, and cultural unevenness', in T. Khoo (ed.), The Body Politic: Racialised Political Cultures in Australia; University of Queensland Australian Studies Centre Conference, University of Queensland Australian Studies Centre and Monash University National Centre for Australian Studies, Brisbane, pp. 1-13.

Dunn, K.M. \& White, A. 2008, Report on 2007 Australian Capital Territory Racism Survey, Challenging Racism: The Anti-racism Research Project, Sydney.

Forrest, J. \& Dunn, K.M. 2006, 'Racism and intolerance in Eastern Australia: a geographic perspective', Australian Geographer, vol. 37, no. 2, pp. 167-186.

Forrest, J. \& Dunn, K.M. 2007, 'Constructing racism in Sydney, Australia’s largest EthniCity', Urban Studies, vol. 44, no. 4, pp. 699-721.

Hall, S. 2000, 'Conclusion: the multi-cultural question', in B. Hesse (ed.), Un/settled Multiculturalisms, Zed Books, London, pp. 209-241.

Hesse, B. 2000, 'Introduction: un/settled multiculturalisms', in B. Hesse (ed.), Un/settled Multiculturalisms, Zed Books, London, pp. 1-30.

Human Rights and Equal Opportunity Commission 1991, Report of the National Inquiry into Racist Violence in Australia, Australian Government Publishing Service, Canberra.

Human Rights and Equal Opportunity Commission 2004, Ismaع Listen: National Consultations on Eliminating Prejudice Against Arab and Muslim Australians, Human Rights and Equal Opportunity Commission, Sydney.

Islamic Council of New South Wales 2004, Challenges for Australian Muslims: Discrimination, Anti-Terrorism and the Media, Islamic Council of New South Wales, Chullora.

Kobayashi, A. \& Peake, L. 2000, 'Racism out of place: thoughts on Whiteness and an antiracist geography in the new millennium', Annals of the Association of American Geographers, vol. 90, pp. 392-403.

Lamont, M., Morning, A. \& Mooney, M. (2002) 'Particular Universalisms: North African Immigrants Respond to French Racism’, Ethnic and Racial Studies, vol. 25, no. 3, pp. 390414.

Loosemore, M. \& Chau, D.W. 2002, 'Racial discrimination towards Asian operatives in the Australian construction industry', Construction Management and Economics, vol. 20, no. 1, pp. 91-102.

McGuiness, M. 2000, ‘Geography matters? Whiteness and contemporary geography', Area, vol. 32, no. 2, pp. 225-230.

Modood, T. 2000, 'Anti-essentialism, multiculturalism, and the 'recognition' of religious groups', in W. Kymlicka \& W. Norman (eds), Citizenship in Diverse Societies, Oxford University Press, Oxford, pp. 175-195. 
Paradies, Y. 2006, 'A systematic review of empirical research on self-reported racism and health', International Journal of Epidemiology, vol. 35, pp. 888-901.

Poynting, S. \& Noble, G. 2004, Living with Racism: The experience and reporting by Arab and Muslim Australians of discrimination, abuse and violence since September 11, 2001, Report to the Human Rights and Equal Opportunity Commission, Centre for Cultural Research, University of Western Sydney.

Thrift, N. 2005, 'But malice aforethought: cities and the natural history of hatred', Transactions of the Institute of British Geographers, vol. 30, pp. 133-150.

Victorian Health Promotion Foundation 2007, More than Tolerance: Embracing Diversity for Health, Victorian Health Promotion Foundation, Melbourne.

Warren, J.W. 2000, 'Masters in the field: white talk, white privilege, white biases', in F.W. Twine \& J.W. Warren (eds), Racing Research, Researching Race: Methodological Dilemmas in Critical Race Studies, New York University Press, New York, pp. 135-164. 